First occurrence of the pterosaur Coloborhynchus (Pterosauria, Ornithocheiridae) from the Wessex Formation (Lower Cretaceous) of the Isle of Wight, England

Corresponding Author

David M. Martill

School of Earth and Environmental Sciences, University of Portsmouth, Portsmouth PO1 3QL, UK david.martill@ port.ac.uk

Tel. $0044(0) 2392842256$ 


\title{
First occurrence of the pterosaur Coloborhynchus \\ (Pterosauria, Ornithocheiridae) from the Wessex \\ Formation (Lower Cretaceous) of the Isle of Wight, England
}

\section{David M. Martill}

School of Earth and Environmental Sciences, University of Portsmouth, Portsmouth PO1 3QL, UK david.martill@port.ac.uk

Keywords: Pterosaur; Ornithocheiridae; Cretaceous; Wessex Formation; Isle of Wight, England

\begin{abstract}
A new specimen comprising a fragmentary pterosaur rostrum can be referred to the ornithocheirid genus Coloborhynchus sp. on account of its anteriorly directed anterior-most teeth located on an upturned palatal surface. The new specimen from the Early Cretaceous Wessex Formation, Wealden Group of the Isle of Wight, southern England is the first record of this taxon from the Barremian and the Isle of Wight.
\end{abstract}

\section{Introduction}

Coloborhynchus is a genus of pterodactyloid pterosaur known from the Early and perhaps Late Cretaceous of both Gondwana and Laurasia (Lee, 1994, Mader and Kellner, 1999; Fastnach, 2001; Martill and Unwin, 2012). It is well known for its remarkable dentition, elaborate sagittal premaxillary crest and its immense wingspan, estimated at over $6.5 \mathrm{~m}$ for some species (Owen 1859; Martill and Unwin 2012). Although Owen originally thought it was a short skulled pterosaur, subsequent discoveries in Brazil have shown it to possess an elongate skull with a sagitally placed crest on the anterior rostrum and mandible (see Veldmeijer 2003; Kellner and Tomida, 2000). 
The genus was first recognised as a distinct taxon by Owen (1874) who named it for a fragment of rostrum comprised mainly of fused premaxillae from the Wadhurst Clay Formation of the Hastings Group of Hastings, East Sussex, in southern England. Despite its fragmentary and highly worn nature, the holotype (NHMUK R1822) was morphologically distinctive, being distinguished by, among other features, a pair of anteriorly directed teeth on a surface that represents a 90 degree upturn of the palate. Other distinctive features include a medially located premaxillary crest, an anterior lateral expansion of the rostrum tip producing a 'spoon-bill' aspect and, for its time, its enormous size. Owen named this first example Coloborhynchus clavirostris, but subsequently, specimens recovered from the slightly younger Cambridge Greensand of Cambridgeshire (C. capito [Seeley, 1870]; C. sedgwicki Owen, 1859) the systematics of which have been reviewed by Unwin (2001). Considerably later, specimens were also discovered in the Americas, with Coloborhynchus wadleigh Lee, 1994 recovered from the Early Cretaceous Paw Paw Formation of Fort Worth, Texas, and $C$. robustus Fastnach, 2001 from the Early Cretaceous (?Albian) Santana Formation of Brazil (Veldmeijer, 2003; Fastnach, 2001). An example was also described from the Kem Kem Beds (?Cenomanian) of south east Morocco (Mader and Kellner, 1999). Named Coloborhynchus moroccensis (Mader and Kellner, 1999), it was originally placed in its own genus, Siroccopteryx. However, the minor differences between it and other Coloborhynchus specimens are probably only relevant at species level (Martill and Unwin, 2012). Indeed, Rodrigues and Kellner (2008) erected the new genus Uktenadactylus for C. wadleighi but the differences between these specimens also seem trivial, and probably only represent species level differences and the validity of the genus Uktendodactylus is rejected here. Describe hear is a distinct fragment of pterosaur rostrum tip from the Isle of Wight, England that, although rather worn, still bears several features that allow it to be assigned with confidence to Coloborhynchus sp. This specimen represents the first occurrence of this taxon in the Wealden Group of the Isle of Wight.

Abbreviations used in this paper: IWCMS Isle of Wight County Museum Service; NHMUK Natural History Museum, London; SMNK Staatliches Museum für Naturkunde Karlsruhe.

\section{Geological setting}

The new specimen was found on the foreshore near Sudmoor Point on the south west coast of the Isle of Wight. Vertebrate fossils are abundant between the point at National Grid 
Reference SZ 39228278 and the beach access at Chilton Chine at SZ 40898210 (Fig. 1). Here the rapidly eroding cliffs of the Wessex Formation of the Wealden Group comprise an argillaceous base of variegated overbank mudstones overlain by approximately 6 metres of the fluvial point-bar Sudmoor Point Sandstone, on the top of which is a bone-bearing plant debris bed (PDB) (Sweetman and Insole, 2010) rich in dinosaur and crocodile remains (Fig. 2). This is PDB L1 of Stewart (1978). It is likely that the new specimen is derived from this PDB which is characterised by an abundance of pyritic material (wood and bone) and sideritic concretions. Two other PDBs are present in higher part of the cliffs that may possibly be the source of the specimen. One of these yields large, articulated unionid bivalves. A detailed section for the Wessex Formation on this part of the Isle of Wight coast is given by Sweetman et al. (2014). No other formation is exposed on this piece of coastline for a distance of some 2 kilometres to the north west and 5 kilometres to the south east. Access is via steps at Chilton Chine, but there is no access at high tide and no way up the cliffs between Chilton Chine and Sudmoor Point.

\section{Systematics}

Pterosauria Kaup, 1834

Pterodactyloidea Plieninger, 1901

Ornithocheiroidea Seeley, 1891 sensu Unwin, 2003

Ornithocheiridae Seeley, 1870

Genus Coloborhynchus Owen, 1874

Specimen: IWCMS 2014.82. Fragment of anterior rostrum.

Locality: Sudmoor Point, Isle of Wight, southern England.

Horizon: One of 3 Plant Debris beds (probably L1 Stewart, 1978) above the Sudmoor Point Sandstone, Wessex Formation, Wealden Group. Early Cretaceous, Barremian (Batten, 2011).

\subsection{Material}

The new specimen (Figs. 3-5), accession number IWCMS 2014.82, comprises the anterior portion of a pterosaur rostrum with an 'upturned' palatal surface displaying the bases of two anteriorly directed teeth broken at the base of the crown. It is beach worn, having been found 
on the foreshore among flint beach pebbles. Although the original bone, tooth enamel and dentine is preserved, void space of the internal trabecular bone has become filled with slightly yellowish calcite and coarsely crystalline pyrite. There is also a thin veneer on the external surface of some of the bone. A large cavity remains unfilled in the centre of the piece when viewed posteriorly.

\subsection{Description}

The specimen has a maximum height of $45 \mathrm{~mm}$, maximum width of $38.5 \mathrm{~mm}$ and is $27 \mathrm{~mm}$ long (anterior to posterior faces). All surfaces except the posterior face are smooth with some of the surface bone eroded away to reveal internal trabecular bone. The posterior surface reflects a rough break that has been slightly worn by marine erosion. Conveniently it reveals an internal foramen that may have housed an air sac or possibly a mechano-sensory organ linked to the trigeminal nerve system. The lateral margins of the rostrum are somewhat concave, depressed to a depth of $1.5 \mathrm{~mm}$. The worn bases of teeth are present in the first pair of dental alveoli, and a tooth is present on the left side of the $2^{\text {nd }}$ alveolar pair. The first alveolar pair are both oval in outline with a maximum diameter of $11.5 \mathrm{~mm}$ and minimum diameter of $7.75 \mathrm{~mm}$. The long axis of the alveolus is ventro-laterally declined at 30 degrees from the horizontal. The first tooth of the left side has a maximum diameter of $11 \mathrm{~mm}$ and minimum diameter of $7 \mathrm{~mm}$. This is $\sim 20 \%$ smaller than the equivalent tooth diameter in a fragmentary Coloborhynchus capito described by Martill and Unwin (2012). The second alveolar pair are somewhat larger and slightly more circular than the first with a maximum diameter $12 \mathrm{~mm}$ and a minimum diameter of $8 \mathrm{~mm}$ on the right side and a maximum diameter $12 \mathrm{~mm}$ and minimum diameter of $9 \mathrm{~mm}$ on the left side. The distance between the first and second alveolar pairs is $7 \mathrm{~mm}$. The palatal surface has a slightly inflated 'bulbous' area between the second pair of alveoli (Figs 3e, 4e) and there is no medial grove on this surface, thus resembling the condition seen in the anterior rostrum of Coloborhynchus robustus (specimen SMNK 2302 PAL)

\section{Discussion}

Although IWCMS 2014.82 is only a very small rostral fragment, it is readily identified as pterosaurian on account of the very thin $(\sim 0.5 \mathrm{~mm})$ nature of the outer bony wall, and as a member of Ornithocheiridae on account of its very large anterior dentition. The upturned 
palatal surface bearing two large anteriorly directed teeth confirms its identity as a species of Coloborhynchus. The slightly bulbous palatal surface between the second alveolar pair compares well with the situation in C. robustus from the Santana Formation of Brazil described by Fastnach $(2001,2008)$. This confirms its identity as a rostral fragment (Fig. 5) and not from the anterior mandibular symphysis where a prominent median groove is present on the palatal surface. The specimen compares closely with the holotype of C. clavirostris, the type species of the genus (Fig. 6). Slight differences include a marginally greater lateral expansion in IWCMS 2014.82, presence of a very shallow sub-circular depression in the upturned palatal surface of NHMUK R 1822 just below the first two teeth and a flatter palatal surface in NHMUK R 1822. These differences are not deemed worthy for species separation.

The new specimen represents the first occurrence of the genus Coloborhynchus in the Wessex Formation of the Isle of Wight. The Wessex Formation pterosaurs were reviewed recently by Sweetman and Martill (2010) who recorded only the ornithocheiroids Istiodactylus latidens (Seeley, 1901) and Caulkicephalus trimicrodon Steel et al., 2005 among the diagnosable specimens. Although both lie within Ornithocheiroidea, they are very distinct pterosaurs. Istiodactylus is typified by a rounded rostrum with numerous closely spaced, isodont teeth with laterally compressed triangular crowns, while those of Caulkicephalus are heterodont, elongate, recurved and caniniform like those of Coloborhyhchus to which it is closely related. The new specimen clearly indicates that Wessex Formation pterosaur diversity is higher than previously reported, and demonstrates affinities with both Chinese and European Early Cretaceous assemblages where istiodactylids are present and Gondwana where Coloborhynchus occurs.

\section{Acknowledgements}

I thank Sandra Chapman and Lorna Steel at the Natural History Museum, London, for allowing me to examine the holotype of $C$. clavirostris. Thanks also to Trevor Price, Gary Blackwell and Alex Peaker at Dinosaur Isle for allowing me to examine the new specimen. Thanks to Dino Frey, Karlsruhe for providing cast of the holotype of C. robustus. I am indebted to Mr Will Thurbin of Niton, Isle of Wight for kindly donating the specimen to the Dinosaur Isle Museum at Sandown. Dr Brian Andres is thanked for photographing the specimen for me. Dr Steve Sweetman and an anonymous referee are thanked for their helpful 
comments. This work was supported by a small grant from the School of Earth and Environmental Sciences, University of Portsmouth.

\section{References}

Batten, D.J., 2011. Wealden Geology. 7-14 In: Batten, D.J. (ed.) English Wealden fossils. Field Guides to Fossils, 14. Palaeontological Association, London, 769 pp.

Fastnacht, M., 2001. First record of Coloborhynchus (Pterosauria) from the Santana Formation (Lower Cretaceous) of the Chapada do Araripe, Brazil. Paläontologische Zeitschrift 75, 23-36.

Fastnach, M., 2008. Tooth replacement pattern of Coloborhynchus robustus (Pterosauria) from the Lower Cretaceous of Brazil. Journal of Morphology 269, 332-348.

Kaup, J., 1834. Versuch einer Eintheilung der Saugethiere in 6 Stämme und der Amphibien in 6 Ordnungen. Isis 3, 311-315.

Kellner, A.W.A., Tomida, Y., 2000. Description of a new species of Anhangueridae (Pterodactyloidea) with comments on the pterosaur fauna from the Santana Formation (Aptian-Albian), northeastern Brazil. National Science Museum Monographs, Tokyo 17, 135 pp.

Lee, Y.-N., 1994. The Early Cretaceous pterodactyloid pterosaur Coloborhynchus from North America. Palaeontology 37, 755-763.

Mader, B.J., Kellner, A.W.A., 1999. A new anhanguerid pterosaur from the Cretaceous of Morocco. Boletim do Museu Nacional, Nova Série. Geologia 45, 1-11.

Martill, D.M., Unwin, D.M., 2012. The world's largest toothed pterosaur, NHMUK R481, an incomplete rostrum of Coloborhynchus capito (Seeley 1870) from the Cambridge Greensand of England. Cretaceous Research 34, 1-9.

Owen, R., 1859. On remains of new and gigantic species of pterodactyle (Pter. Fittoni and Pter. Sedgwickii) from the Upper Greensand, near Cambridge. Report of the British Association for the Advancement of Science, Leeds, 1858, pp. 98-103.

Owen, R., 1874. Fossil Reptilia of the Mesozoic Formations, I Pterosauria. Monographs of the Palaeontographical Society 27, 1-14.

Plieninger, F., 1901. Beiträge zur Kenntnis der Flugsaurier. Palaeontographica 48, 65-90. 
Rodrigues, T., Kellner, A.W.A., 2008. Review of the pterodactyloid pterosaur Coloborhynchus. Zitteliana 28, 219-228.

Seeley, H.G., 1870. The Ornithosauria. An Elementary Study of the Bones of Pterodactyls, Made From Fossil Remains Found in the Cambridge Upper Greensand, and Arranged in the Woodwardian Museum of the University of Cambridge. Deighton, Bell \& Co., Cambridge xii +135 pp.

Seeley, H.G., 1891. On the shoulder girdle in Cretaceous Ornithosauria. Annals and Magazine of Natural History, 6 (7), 438-445.

Seeley, H.G., 1901. Dragons of the air: an account of extinct flying reptiles. Methuen, London: xiii +239 pp.

Steel, L., Martill, D.M., Unwin, D.M., 2005. A new pterodactyloid pterosaur from the Wessex Formation (Lower Cretaceous) of the Isle of Wight. Cretaceous Research 26, 686-698.

Stewart, D.J., 1978. The sedimentology and palaeoenvironment of the Wealden Group of the Isle of Wight, southern England. Unpublished PhD thesis, Portsmouth University, 347 pp. + appendices.

Sweetman, S.C., Goedert J., Martill, D.M., 2014. A preliminary account of the fishes of the Lower Cretaceous Wessex Formation (Wealden Group, Barremian) of the Isle of Wight, southern England. Biological Journal of the Linnean Society, 113, 872-896.

Sweetman, S.C., Insole, A.N., 2010. The plant debris beds of the Early Cretaceous (Barremian) Wessex Formation of the Isle of Wight, southern England: their genesis and palaeontological significance. Palaeogeography, Palaeoclimatology, Palaeoecology 292, 409-424.

Sweetman, S.C., Martill, D.M., 2010. Pterosaurs of the Wessex Formation (Early Cretaceous, Barremian) of the Isle of Wight, southern England: a review with new data. Journal of Iberian Geology 36, 225-242.

Unwin, D.M., 2001. An overview of the pterosaur assemblage from the Cambridge Greensand (Cretaceous) of eastern England. Mitteilungen aus dem Museum für Naturkunde, Berlin. In: Geowissenschaftlichen, Reihe 4, 189-221.

Veldmeijer, A.J., 2003. Description of Coloborhynchus spielbergi sp. nov. (Pterodactyloidea) from the Albian (Lower Cretaceous) of Brazil. Scripta Geologica 125, 35-139. 


\section{FIGURE CAPTIONS}

Fig. 1. A, Map showing the outline geology of the Isle of Wight. The specimen described here comes from the Wessex Formation of the Wealden Group and was found on the foreshore at Sudmoor Point (arrowed).

Fig. 2. Simplified stratigraphic log of the cliff exposure at Sudmoor Point. On the Isle of Wight the exposed Wessex Formation is entirely Barremian. The late Berriasian base of the formation is not seen on the island, but has been proved in boreholes, and the overlying Late Barremian-Early Aptian Vectis Formation is not present at this locality.

Fig. 3. Anterior rostrum fragment of Coloborhynchus sp. IWCMS 2014.82. a, right lateral view; b, anterior view; c, left lateral view; d, posterior view; e, palatal view; f, dorsal view. Arrows point to anterior. Scale bar $=10 \mathrm{~mm}$.

Fig. 4. Line drawings of anterior rostrum fragment of Coloborhynchus sp. IWCMS 2014.82. a, right lateral view; b, anterior view; c, left lateral view; d, posterior view; e, palatal view; f, dorsal view. Arrows point to anterior. Scale bar $=10 \mathrm{~mm}$.

Fig. 5. Outline of skull of Coloborhynhcus with location of IWCMS 2014.82 indicated.

Fig. 6. Coloborhynchus compared in anterior view. a, holotype and type species of Coloborhynchus, C. clavirostris, NHMUK R 1822; b, Coloborhynchus sp. from the Wessex Formation of the Isle of Wight, IWCMS 2014.82. 